УКРАЇНОМОВНА АДАПТАЦІЯ ОПИТУВАЛЬНИКА МЕНТАЛІЗАЦІї НА НЕКЛІНІЧНІЙ ВИБІРЦІ

\title{
UKRAINIAN LANGUAGE ADAPTATION OF THE MENTALIZATION QUESTIONNAIRE IN NON-CLINICAL SAMPLES
}

УДК 159.942.3.072.4

DOI https://doi.org/10.32843/2663-

5208.2020.17.23

\section{Турецька X.I.}

к.психол.н.

доцент кафедри психології

та психотерапії

Український католицький університет

Кунікевич Б.І.

бакалавр кафедри психології

та психотерапії

Український католицький університет
Під менталізацією розуміють фоокусування на психічних станах при поясненні власноі поведінки та поведінки інших. Автори кончепту Е. Бейтман і П. Фонагі визначають менталізацію як осмислення дій, власних $i$ тих, що здійснюють інші, на підставі навмисних психічних станів, таких як бажання, почуття й переконання. Численні дослідження доводять, що здатність до менталізації тісно пов'язана з психічним здоров'ям особистості. Погіршена здатність до менталізації корелює з психічними розладами, низьким адаптаційними можливостями та психологічним дистресом. Опитувальник вимірювання рівня менталізації MZQ, розроблений Гаузбергом та ін., зарекомендував себе як швидкий, якісний $і$ досить надійний метод оцінювання рівня менталізаціі й адаптований на італійській та іспанській вибірках. Завданням дослідження було адаптувати опитувальник MZQ на україномовній неклінічній вибірці. Запитання опитувальника менталізації (15 пунктів) формують чотири шкали: відмова від саморефрлексії, емоційне усвідомлення, режим психічної еквівалентності, регуляція афекту. У ході емпіричного дослідження здійснено лінгвістичну адаптацію опитувальника MZQ. Установлено показник внутрішньої узгодженості опитувальника (Cronbach's Alpha $=0,75$ ) показник ретестової надійності ( $r=0,75$, $p<0,01)$. За результатами аналізу фракторної структури методики виділено чотири фрактори, що збігаються з кількістю фракторів у теоретичній моделі, проте змістовно лише частково відповідають англомовній версії. Конструктна валідність оцінювалася шляхом кореляції показників $M Z Q$ зі шкалами інших психодіагностичних методик: емпатії $(r=0,25, p<0,05)$, алекситимі $(r=0,36, p>0,05)$, прив'язаності - установлено кореляції між порушеною здатністю до менталізації та шкалами уникнення $(r=0,28$, $p<0,05)$, амбівалентністю занепокоєння $(r=0,31, p<0,05)$ та амбівалентністю заглиблення в себе $(r=0,31, p<0,05)$. Отже, адаптована україномовна версія методики $M Z Q$ володіє задовільними показниками надійності й валідності, може вважатися якісним інструментом вимірювання здатності до менталізації.

Ключові слова: опитувальник менталізаціі (MZQ), україномовна адаптація MZQ, здат- ність до менталізації, надійність тесту, валідність тесту.

Mentalization is understood as focusing on mental states in explaining one's own behavior and the behavior of others. The authors of the concept, A. Bateman and P. Fonagi, define mentalization as the comprehension of actions, one's own and those performed by others, on the basis of intentional mental states, such as desires, feelings, and beliefs. Numerous studies show that the ability to mentalize is closely linked to a person's mental health. Impaired ability to mentalize correlates with mental disorders, low adaptability and psychological distress. The Mentalization Questionnaire (MZQ) was developed by Hausberg et al. and is a fast, high-quality, and reliable method of assessing the level of mentalization. It has been adapted on the Italian and Spanish samples. The aim of this study was to adapt the Mentalization Questionnaire (MZQ) on a Ukrainian-language non-clinical sample. The questions of the mentalization questionnaire (15 points) form four scales: refusal of self-reflection, emotional awareness, regime of mental equivalence, regulation of affect. In the course of empirical research, a linguistic adaptation of the $M Z Q$ questionnaire was performed. The internal consistency of the questionnaire (Cronbach's Alpha $=0.75)$ and the retest reliability $(r=0.75$, $p<0.01$ ) were established. According to the results of the analysis of the factor structure of the $M Z Q$, four factors are identified, which coincides with the number of factors in the theoretical model, but the content only partially corresponds to the English version. Constructive validity was assessed by correlating MZQ scales with scales of other psychodiagnostic tests: empathy $(r=0.25, p<0.05)$, alexithymia $(r=0.36, p>0.05)$, and attachment - correlations were established between impaired mentalization and avoidance scales ( $r=0.28, p<0.05)$, anxiety ambivalence $(r=0.31, p<0.05)$, and self-deepening ambivalence $(r=0.31, p<0.05)$. Thus, the adapted Ukrainian version of the Mentalization Questionnaire (MZQ) has satisfactory indicators of reliability and validity, and can be considered a quality tool for measuring the ability to mentalize. Key words: Mentalization Questionnaire (MZQ), Ukrainian adaptation of MZQ. Mentalization ability, Test Validity, Test Reliability.
Постановка проблеми. Поняття «менталізація» в останні роки широко застосовується як теоретична концепція та методичний прийом у різних психотерапевтичних напрямах: у когнітивно-поведінковій терапії, психоаналітичній і психодинамічній терапії. Утім в Україні метод психотерапії, що ґрунтується на менталізації (mentalization-based treatment - MBT), не знайшов ще достатнього розповсюдження. Психотерапевтичний підхід «психотерапія, що ґрунтується на менталізації», розроблений Е. Бейтманом і П. Фонагі в 1999 р. в рамках психодинамічної терапії, зарекомендував себе як один із найбільш ефективних у роботі з межовими розладами особистості [7]. Дослідження показали помітне зниження рівня 
суїцидальних думок, зниження потреби в медикаментах і зростання показників психологічного функціонування особистості при застосуванні психотерапії, що ґрунтується на менталізації [4; 5; 6; 7]. Адаптація методики вимірювання рівня менталізації (MZQ) як розвиток інструментарію для емпіричного вимірювання здатності до менталізації може дати поштовх до подальшого розвитку й упровадження в українську психотерапевтичну практику технік і підходів, що ґрунтуються на менталізації.

Аналіз останніх досліджень і публікацій. Уперше термін «менталізація» вжито Пітером Фонагі та Ентоні Бейтманом у 1989 році. У першій статті, що розглядала ідеї менталізації, дослідниками висловлено припущення, що репрезентація себе та інших через мислення, переконання, бажання не 3'являється у віці 4-х років як наслідок дорослішання, а радше $\epsilon$ досягненням розвитку, яке глибоко вкорінене в якості стосунків з ранніми об'єктами. Іншими словами, здатність до менталізації є дозріваючою (подібно до лінгвістичних здібностей) і зазвичай виникає в контексті стосунків прив'язаності, які полегшують ідентифікацію власних станів, а також ідентифікацію станів батьківських фігур у контексті міжособистісних взаємодій, іноді в емоційно заряджених ситуаціях.

Натепер під менталізацією розуміють фокусування на психічних станах, особливо при поясненні власної поведінки й поведінки інших. Дослідники Бейтман і Фонагі визначають менталізацію як осмислення дій, власних і тих, що здійснюють інші, на підставі навмисних психічних станів, таких як бажання, почуття й переконання [5]. Іншими словами, менталізацію можна пояснити як явище осягнення та інтерпретації поведінки у зв'язку з інтенціональними психічними станами. Щоб увійти в позицію менталізації, ми повинні визнавати те, що й в інших, і в нас самих є свідомість (mind). Тому менталізацію ще часто називають уявним психічним процесом, оскільки індивіду доводиться уявляти, що саме думає чи переживає інша людина. Хоч явище менталізації задіює складні когнітивні процеси, воно великою мірою є передсвідомим феноменом [3].

У сучасному контексті явище менталізації застосовують при поясненні багатьох психологічних концепцій і теорій. Також численні дослідження свідчать про її зв'язок із фундаментальними поняттями, наприкладу, з емпатією, схильністю до самоаналізу (psychological mindedness), усвідомленістю (mindfulness), схильністю до аналізу психіки (mindmindedness), з одним із ключових понять при розумінні менталізації - з прив'язаністю [5]

Дослідження показують, що погіршена здатність до менталізації значно корелює з психічною дисфункцією, низьким адаптацій- ними можливостями та суб'єктивним дистресом; загалом у популяції індивіди варіюються залежно від рівня та стилю менталізації, що, у свою чергу, має великі наслідки для їхнього життєвого шляху [5].

Існують дослідження того, що дитяча травма прив'язаності погіршує здатність до роздумів про психічні стани, іншими словами, до менталізації. Зокрема, дослідження Бартлса та Зекі виявило, що при патологічній активації системи прив'язаності ділянки мозку, які пов'язують із соціальним судженням і менталізацією, гальмуються [4].

Означення менталізації як однієї з основних концепцій при роботі з пацієнтами з межовим розладом особистості сприяло тому, що цей феномен активно почали досліджувати та застосовувати клініцисти в різних країнах. Оскільки розроблений Гаузберг та ін. опитувальник вимірювання рівня менталізації MZQ сформований як кількісний метод дослідження, через самооцінювання свого стану пацієнтами, він зарекомендував себе як швидкий, якісний і досить надійний метод оцінювання рівня менталізації [10].

Така простота дослідження не залишила байдужими й дослідників з інших країн, тому натепер існує адаптація MZQ в Італії [15] та Іспанії [14]. За даними перелічених досліджень, опитувальник вимірювання рівня менталізації MZQ зарекомендував себе як точний і надійний інструмент діагностики в кожному із цих культурних контекстів; іспанська версія свідчить про достатній рівень внутрішньої узгодженості (Cronbach's Alpha $=0,79$ ) та адекватну ретестову надійність $(\mathrm{ICC}=0,65)$. Важливо зазначити, що в разі адаптації італійського та іспанського опитувальника $\mathrm{MZQ}$ вибірка формувалася на основі віку - для MZQ-IT (італійська версія) - це досліджувані віком від 14 до 25 років, для MZQ в іспанській адаптації - це підлітки та юнаки віком 12-19 років. Не менш важливим є той факт, що вибірка іспанської адаптації не була клінічною. У роботі над адаптацією методики в Україні фактор віку не враховувався.

Постановка завдання. Мета статті - адаптувати опитувальник $\mathrm{MZQ}$ на україномовній неклінічній вибірці.

Виклад основного матеріалу дослідження. В адаптації методики менталізації на україномовній неклінічній вибірці взяло участь 186 респондентів, із них - 133 жінки і 53 чоловіки. Середній вік респондентів становив 24 роки. Діапазон віку від наймолодшого досліджуваного - 14 років, до найстаршого 64. При проведенні повторного опитування для встановлення ретестової надійності вибірка налічувала 122 респонденти, з них - 85 жінок і 37 чоловіків. Розподіл досліджуваних за віком зберігся. 
Збір даних відбувався за допомогою застосування онлайн форми опитування на платформі Google Forms.

Для проведення дослідження застосовано чотири методики, а саме: діагностику емпатії (модифікований опитувальник А. Меграбяна, М. Епштейна), торонтську алекситимічну шкалу (TAS) (Дж. Тейлор), адаптовану в Психоневрологічному інституті імені В.М. Бехтерєва, тест на визначення якості прив'язаності (Measure of Attachment Qualities - MAQ) (К.С. Карвер), адаптований російською мовою К. Чистопольською, О. Мітіною та ін. [1], та опитувальник рівня менталізації (The Mentalization Questionnaire) М. Гаузберг, переклад якого здійснений в рамках дослідження.

Питанняопитувальникаменталізації(15пунктів) базуються на теорії П. Фонагі й Е. Бейтмана про концепт менталізації та формують 4 шкали: 1) відмова від саморефлексії - діагностує схильність до уникнення думок, відкидання почуттів чи внутрішніх станів, власних або іншої людини, 2) емоційне усвідомлення - вимірює, наскільки опитуваний здатен до ідентифікації й диференціації внутрішніх станів, власних чи інших людей, 3) режим психічної еквівалентності - вимірює тенденцію до ототожнення внутрішнього стану із зовнішньою реальністю, іншими словами, вимірює, наскільки уявлена критична ситуація може мати такий же емоційний вплив на людину, як і фактично пережита, 4) регуляція афекту - оцінює здатність до модуляції (контролю) афекту, власного чи інших; високі показники за цією шкалою свідчитимуть про можливе почуття страху перед власними емоціями, безпомічність у їх регулюванні.

Питання оцінюються за шкалою від 1 до 5 (абсолютно не згоден - 1 бал; скоріше не згоден - 2 бали; ні те, ні інше - 3 бали; скоріше згоден - 4 бали; абсолютно згоден - 5 балів). Відповідно, діапазон отриманих балів коливається від 15 до 75 балів.

Запитання методики вимірювання здатності до менталізації MZQ

Відмова від саморефлексії

1. Більшість часу (здебільшого) мені не подобається говорити про свої думки та почуття з іншими.

2. Говорити про почуття - означало б, що вони стають усе сильнішими.

3. Якщо хтось позіхає в моїй присутності, це надійний знак того, що йому нудно в моїй компанії.

4. Більшу частину часу краще нічого не відчувати.

\section{Емоційне усвідомлення}

5. Іноді я усвідомлюю свої почуття лише ретроспективно (після того, як вони вже відбулися).

6. Часто мені важко сприймати свої почуття з повною інтенсивністю.
7. Часто я навіть не знаю, що відбувається всередині мене.

8. Я схильний ігнорувати почуття фізичного напруження чи дискомфорту, поки вони не звернуть на себе моєї повної уваги.

Режим психічної еквівалентності

9. Часто я відчуваю загрозу від думки, що хтось міг би мене критикувати чи ображати.

10. Якщо я очікую, що мене піддадуть критиці чи образі, мій страх зростає все більше і більше.

11. Я вірю в те, що можу справді комусь дуже подобатися, якщо в мене $є$ достатньо реалістичних доказів для цього (наприклад: побачення, подарунок або обійми).

12. Мені важко повірити, що стосунки можуть змінюватися.

Регуляція афекту

13. Часто я не можу контролювати свої почуття.

14. Пояснення інших людей мало допомагають зрозуміти мої почуття.

15. Іноді почуття для мене небезпечні.

Інтерпретація результатів відбувається після підрахунку суми балів за всіма шкалами. При поясненні застосовуємо обернену кореляцію: чим більша сума балів, тим нижча здатність до менталізації в опитуваного.

На першому етапі дослідження здійснено лінгвістичну адаптацію методики вимірювання рівня менталізації MZQ. Для цього опитувальник перекладено українською мовою шляхом залучення спеціалістів у сфері психології, які вільно володіють українською та англійською мовами. Для початку здійснений переклад методики з мови оригіналу українською зі збереженням смислових конструкцій. Після зворотного перекладу носієм мови обидва варіанти пройшли експертну оцінку, і симетричний переклад відкоректований для більш точної відповідності з оригіналом.

За даними обчислень мір центральної тенденції для загальної вибірки, отримані результати не мають різких викидів значень. Показники середнього значення, медіани та моди перебувають на близькому за значеннями рівні.

Про нормальний розподіл значень також свідчить показник рівня значущості критерію Шапіро-Вілкса ( $p=0,26 ; p>0,05)$.

\section{Нормативні показники україномовної версії методики}

\begin{tabular}{|l|c|c|c|}
\hline & $\begin{array}{c}\text { Загальна } \\
\text { вибірка }\end{array}$ & Чоловіки & Жінки \\
\hline $\begin{array}{l}\text { Середнє } \\
\text { значення (M) }\end{array}$ & 43,84 & 39,18 & 42,36 \\
\hline $\begin{array}{l}\text { Стандартне } \\
\text { відхилення } \\
\text { (SD) }\end{array}$ & 8,81 & 7,37 & 8,11 \\
\hline
\end{tabular}


Для перевірки внутрішньої узгодженості опитувальника використано аналіз коефіцієнтів Альфа-Кронбаха. Отриманий результат Cronbach's Alpha $=0,75$ можна вважати задовільним, беручи до уваги показник оригінальної версії методики, який коливається в межах 0,54 до 0,72 у різних вибірках.

При факторному аналізі за методом головних компонент з обертанням варімакс виділено 4 фактори на підставі критерію кам'яного осипу. За результатами аналізу факторних навантажень, виділяються чотири фактори, що збігається з кількістю факторів у теоретичній моделі, проте можна стверджувати, що змістовно ці фактори лише частково відповідають англомовній версії методики. За здійсненим у роботі аналізом, фактор № 1 «відмова від саморефлексії» утворюють питання 4, 5, $6,7,8$, що, за винятком 4 питання, не відповідає оригіналу методики, де ця шкала утворена питаннями $1,2,3,4$. Беручи до уваги питання, які виділив аналіз першого фактору, ми можемо припустити спорідненість шкали № 1 «відмова від саморефлексії» та № 2 «емоційне усвідомлення» (яка в оригіналі вимірюється саме питаннями $5,6,7,8)$ і спробувати пояснити це наявністю оберненої кореляції, припускаючи, що високий показник відмови від саморефлексії може мати зв'язок з низьким рівнем емоційного усвідомлення.

Згідно з аналізом, до фактору № 2 «емоційне усвідомлення» належать питання $1,2,12$, 13,15 . В оригіналі методики ці питання розподілені за шкалами «відмова від саморефлексії» (питання 1, 2), «режим психічної еквівалентності» (питання 12) та шкалою «регуляції афекту» (питання 13, 15). Такі дані можуть свідчити про можливість розподілення питань за трьома факторами, відмовившись в адаптації української методики від шкали № 2. Звертаючи увагу на текст питань, можна помітити, що їх важко чітко виокремити в окремі шкали без допомоги факторного аналізу, оскільки поняття, які вимірюються методикою, є дуже близькими між собою. Наприклад, питання 2 «говорити про почуття - означало б, що вони стають все сильнішими», яке дослідження виділяє у факторі 2 «емоційне усвідомлення», а в оригіналі методики описується через шкалу 1 «відмова від саморефлексії», проте семантично це питання близьке за значенням як до шкали № 1, так і до шкали № 2.

Фактор № 3 утворюють питання 9, 10, 13 «режим психічної еквівалентності». Цей фактор можна вважати більш спорідненим з оригіналом методики, де так само в цій шкалі виділяються питання 9 і 10. Питання 13 «Часто я не можу контролювати свої почуття», за англомовною методикою вимірювання рівня менталізації MZQ, належить до шкали «регуляція афекту».
Питання 3, 11, 12, 14 утворюють фактор № 4 - «регуляція афекту». Лише питання 14 «Пояснення інших людей мало допомагають зрозуміти мої почуття» згадується в авторському варіанті методики як таке, що підпадає під фактор № 4.

Отже, розподіл питань україномовної версії методики лише частково наближений до оригінального опитувальника вимірювання рівня менталізації MZQ. Це може бути спричинено тим, що структурно шкали вимірюють дуже близькі за значенням поняття, що завдає труднощів для їх чіткого розділення та створює можливість взаємозамінності питань між собою.

Ретестова надійність методики. Через чотири місяці після проведення першого етапу дослідження учасникам надіслано форму опитувальника вимірювання рівня менталізації MZQ для повторного проходження. Зі 186 респондентів першого етапу повторно погодилося відповісти 122, з них - 85 жінок і 37 чоловіків. Отриманий показник ретестової кореляції становив $r=0,75, p<0,01$, що є задовільним показником ретестової надійності, отже, можна вважати методику MZQ досить надійною. Також такий висновок щодо надійності української адаптації MZQ ми можемо робити, посилаючись на дані оригінального дослідження адаптації MZQ М. Гаузберг, де показник ретестової надійності становив 0,76.

Конструктна валідність методики оцінювалася на основі аналізу показників коефіцієнтів кореляції шкал методики вимірювання рівня менталізації MZQ зі шкалами інших валідизованих психодіагностичних методик, що вимірюють близькі до менталізації феномени, a саме: емпатією, алекситимію та прив'язаністю. Загалом результати вказують на кореляцію показників методики менталізації зі шкалами перелічених, що може свідчити про високу конструктну валідність.

Показник кореляції менталізації з алекситимією $(r=0,36, p>0,05)$ указує на зв'язок цих психологічних властивостей, а саме: чим вищим $є$ показник нездатності до менталізації, вимірюваний MZQ, тим вищий показник рівня алекситимії за методикою Торонтської алекситимічної шкали (TAS). Отримані результати співвідносяться з даними нейробіологічних досліджень, котрі вказують, що алекситимія пов'язана з порушенням менталізації, а саме обидва поняття пов'язані з гіпоактивністю в медіальній префронтальній корі мозку [11]. Дослідження вказує на кореляцію між балом менталізації, виміряним за допомогою ФМРТ сесії, використовуючи візуальні анімації ToM (Theory of Mind, іншими словами здатність до менталізації), і балом опитувальника алекситимії TAS: $p=0,030$ за шкалою наміру (Intentionality); та $p=0,026$ за шкалою 
відповідності (Appropriateness). Також зв'язок цих понять часто описують через наявність характеристик як алекситимії, так і дефіциту менталізації при психічних розладах різної нозології чи порушеннях певних психічних властивостей. Наприклад, при порушенні здатності ідентифікувати емоції за виразом обличчя чи межових розладах відмічають як виражені прояви алекситимії, так і знижену здатність до менталізації [2], [8].

Кореляційний аналіз показників менталізації MZQ та прив'язаності здійснювався за розподілом останньої на шкали: безпека, уникнення, амбівалентність занепокоєння, амбівалентність заглиблення в себе. Отримано результати, що свідчили про наявність кореляції між порушеною здатністю до менталізації та шкалами уникнення $(r=0,28$, $\mathrm{p}<0,05)$, амбівалентністю занепокоєння $(r=0,31, p<0,05)$ та амбівалентністю заглиблення в себе $(r=0,31, p<0,05)$. Відповідно, не спостерігається зв'язку нездатності до менталізації зі шкалою безпеки $(r=0,06, p>0,05)$. В оригінальному дослідженні $M$. Гаузберг також береться до уваги поняття прив'язаності, яке вчені досліджують на основі методики Bielefeld Partnership-Expectations Questionnaire (BPEQ). Отримані авторами результати свідчать, що пацієнти з безпечною прив'язаністю показують набагато вищі показники здатності до менталізації за методикою MZQ порівняно з пацієнтами, що класифікуються іншим типом прив'язаності.

Цікавою $є$ кореляція методики менталізації MZQ з показником емпатії за методикою діагностики А. Меграбян та М. Епштейн. Оскільки MZQ характеризується оцінкою менталізації в категорії «низької здатності» до неї, за теоретичною моделлю отриманий показник не може свідчити про пряму кореляцію між методиками. Проте в роботі ми можемо спостерігати неочікуваний результат: кореляцію між цими двома поняттями $(r=0,25, p<0,05)$. Розглянувши детальніше цей випадок, установили, що це зумовлено не загальним показником емпатії як такої, а відповідями на питання, які конкретно пов'язані з емоційним зараженням. До таких належать питання методики емпатії № 3, 6, 8, 11, 13, 15, 16, 18, 19, 22, 23, 24. Характерним для цих питань $€$ наявність таких слів як «хтось поруч», «оточуючі мене люди», «коли хтось..., тоді і я....» тощо. Тобто можна стверджувати, що існує зв'язок порушеної здатності до менталізації з схильністю до емоційного зараження від інших людей. Це може пояснюватися даними, отриманими при дослідженні пацієнтів з межовим розладом особистості, яким притаманна занижена здатність менталізації та занижена здатність до когнітивної емпатії [13]. Проте виділяють ще окреме поняття афективної, або емоційної, емпатії, яка, на противагу когнітивній, є типовою для межових пацієнтів. Вона передбачає автоматичне віддзеркалення емоцій іншої людини або, іншими словами, вже згадане нами «емоційне зараження».

Висновки 3 проведеного дослідження. Менталізація - процес осмислення дій, своїх та інших людей на основі навмисних психічних станів, таких як бажання, почуття й переконання. Такий термін уперше вжито Пітером Фонагі та Ентоні Бейтманом у 1989 році. Розроблений М. Гаузберг та ін. у 2012 році опитувальник вимірювання рівня менталізації MZQ сформований як кількісний метод дослідження цього явища через самооцінювання свого стану пацієнтами. Він зарекомендував себе як швидкий, якісний і досить надійний метод оцінювання рівня менталізації. Такі позитивні характеристики методики сприяли поширенню іï адаптації в інших країнах. Натепер існують адаптації MZQ в Італії та Іспанії, а робота має на меті додати до цього списку й Україну.

У дослідженні встановлено, що порушена здатність до менталізації має зв'язок із наявністю алекситимії, тобто, чим вищий показник нездатності до менталізації вимірюваний MZQ, тим вищий показник рівня алекситимії за методикою Торонтської алекситимічної шкали (TAS).

Також при розрахунку конструктної валідності встановлено, що порушена здатність до менталізації корелює зі шкалами опитувальника прив'язаності, які потенційно свідчать про наявність уникаючого й амбівалентного типу прив'язаності в ранньому дитинстві. Такі результати великою мірою збігаються з теоретичними уявленнями про розвиток порушень менталізації у зв'язку з порушенням ранньої прив'язаності.

Цікавим результатом дослідження можна вважати кореляцію порушеної здатності до менталізації з показником емпатії в категорії, яку дослідження визначає як «емоційне зараження від інших людей». Це можна пояснити властивостями афективної емпатії, що передбачає емоційне віддзеркалення в людей, які не володіють достатнім рівнем менталізації, щоб застосовувати зліші механізми когнітивної емпатії.

Серед обмежень методики можна виділити те, що адаптація проведена на неклінічній вибірці, що не дає повною мірою оцінити порушення цієї здатності, наприклад, у пацієнтів з межовим розладом, у контексті яких зазвичай потрібне тестування менталізації. Це може бути вектором розвитку наступних досліджень при адаптації MZQ.

Загалом адаптована україномовна версія методики MZQ володіє задовільними показниками надійності й валідності, може вважатися якісним інструментом вимірювання здатності до менталізації. 


\section{ЛITЕРАТУРА:}

1. Чистопольская К. Адаптация краткой версии «Переработанного опросника - Опыт близких отношений». Психологический журнал. 2018. C. $87-98$.

2. Alexithymia in schizophrenia: An exploratory study. Psychological Reports. 2001. № 89. P. 95-98.

3. Allen J. Handbook of Mentalization-Based Treatment. 2006.

4. Bateman A., Fonagy P. Effectiveness of psychotherapeutic treatment of personality disorder. British Journal of Psychiatry. 2000. № 177. P. 138-143.

5. Bateman A., Fonagy P. Mentalization-based treatment of BPD. Journal of Personality Disorders. 2004. №18. P. 36-51.

6. Bateman A., Tyrer P. Psychological treatment for personality disorders. Advances in Psychiatric Treatment. 2004. № 10. P. 378-388.

7. Bateman A., Fonagy P.The Development of Borderline Personality Disorder - A Mentalizing Model. Journal of Personality Disorders. 2008. № 22. P. 4-21.

8. Donges U., Kersting A., Suslow T. Alexithymia and perception of emotional information: $A$ review of experimental psychological findings. Universitas Psychologica. 2014. № 13. P. 745-756.
9. Fonagy P., Luyten P., Strathearn L. Borderline personality disorder, mentalization, and the neurobiology of attachment. Infant. Mental Health Journal. 2011. № 32. P. 47-69.

10. Hausberg M., Schulz H., Piegler T. Is a selfrated instrument appropriate to assess mentalization in patients with mental disorders? Development and first validation of the Mentalization Questionnaire (MZQ). Psychotherapy Research. 2012. № 22. P. 699-709.

11. Impaired self-awareness and theory of mind: An fMRI study of mentalizing in alexithymia. Neurolmage. 2006. № 32. P. 1472-1482.

12. Impaired Verbal and Nonverbal Emotion Recognition in Alexithymia Psychosomatic Medicine. 1996. № 58. P. 203-210.

13. Niedtfeld I. Experimental investigation of cognitive and affective empathy in borderline personality disorder: Effects of ambiguity in multimodal social information processing. Psychiatry Research. 2017. № 253. P. 58-63.

14. Spanish adaptation of the Mentalization Questionnaire ( MZQ): psychometric properties in a sample ofadolescents. Eur. Child Adoles. Psy. 2015. № 24. P. 218-218.

15. The Italian adaptation of the Mentalization Questionnaire (MZQ-IT) TPM. 2019. P. 29-38. 